\title{
Body weight gain and voluntary feed intake in meat goat does fed endophyte-infected and endophyte-free tall fescue seed
}

\author{
R. BROWNING, Jr., B. DONNELLY, T. PAYTON, P. PANDYA and M. BYARS \\ Tennessee State University-IAgER, Nashville, TN 37209-1561, USA
}

rbrowning@tnstate.edu

\begin{abstract}
Tall fescue is the primary pasture forage offered to goats in the southeastern United States. Data on how tall fescue endophyte (Neotyphodium coenophialum) affects meat goat performance are lacking. In three summers, yearling does were fed diets containing tall fescue seed to assess the effect of endophyte infection on goat growth and feed intake. In 2004 and 2005, does were fed endophyte-infected (EI) or endophyte-free (EF) tall fescue seeds added to the diets for $10 \mathrm{wk}$. Feed refusals were weighed daily. The EI diet reduced $(\mathrm{P}<0.05)$ weight gain and increased $(\mathrm{P}<0.05)$ feed refusals during each year. In 2006, feed refusal values of EI pens were used to adjust feed offering to EF pens daily. When feed intake was equalised daily during treatment, weight gain was still reduced by the EI diet. These data suggest that endophyte infection in tall fescue can adversely affect meat goat performance.
\end{abstract}

Keywords: goats, tall fescue, endophyte, weight gain, feed intake

\section{Introduction}

Tall fescue (Festuca arundinacea) is used extensively in the U.S. for grazing livestock. The fungal endophyte Neotyphodium coenophialum infects most tall fescue pastures (Bacon \& Siegel 1988; Glenn et al. 1996). The endophyte produces ergot alkaloids that are beneficial to grass performance, but are detrimental to animal performance. Meat goats represent an emerging livestock class in the U.S. often raised on tall fescue. This project investigated the potential of endophyte-infected tall fescue to adversely affect meat goat performance.

Along with tall fescue, numerous other grasses are infected with Neotyphodium spp. endophytes, most notable is perennial ryegrass (Lolium perenne) infected with $N$. lolii (Joost 1995). Consumption of Neotyphodium-infected grasses by livestock causes toxicoses (e.g. fescue toxicosis, ryegrass staggers) that result in significant production and economic losses (Ball 1997; Foot 1997). Reproductive rates, milk yield, and growth rates in livestock are each negatively impacted by ingesting Neotyphodium. Fescue toxicosis is a condition that affects various ruminant species, including cattle (Paterson et al. 1995; Browning 2004), sheep (Aldrich et al. 1993; Kramer et al. 1999) and deer (Wolfe et al. 1998). Manifestations of fescue toxicosis may vary somewhat from species to species (Porter \& Thompson 1992).

Despite the worldwide scope of goat production and the global significance of Neotyphodium/animal interactions, the occurrence of toxicosis in goats eating Neotyphodium-infected grass is not well documented. In one case, goat kids consuming fescue (Festuca octoflora) experienced ergot poisoning (Hibbs \& Wolf 1982). The cause was attributed to ergotised (Claviceps) seed heads. Neotyphodium infection of the grass was not considered in the case report.

Goats are considered intermediate feeders, unlike cattle or sheep that are classified as grazers. However, the feeding behaviour of goats is adaptive and they will consume more grass when available and other forage types (browse and forbs) are in short supply. This is often the case in management systems of the southeastern US in which meat goats are maintained on pasture and hay. A survey of Tennessee goat producers revealed that twothirds of pastures used by goat producers are classified as tall fescue (Leite-Browning et al. 2002). The objective of this study was to evaluate the influence of consuming tall fescue infected with Neotyphodium on meat goat weight gain.

\section{Materials and Methods}

In three successive years, yearling meat goat does (Capra hircus) were fed diets containing tall fescue seed to assess the

Table 1 Composition (as-fed) of seed-treated supplement provided to does each summer.

\begin{tabular}{lcccccc}
\hline & \multicolumn{2}{c}{--- 2004 $^{----}$} & \multicolumn{2}{c}{--- 2005 --- } & \multicolumn{2}{c}{----2006 --- } \\
& El & EF & El & EF & El & EF \\
\hline TDN, \% & 73.62 & 72.99 & 69.76 & 69.64 & 73.26 & 74.25 \\
CP, \% & 15.01 & 14.61 & 14.57 & 14.62 & 15.06 & 14.91 \\
Ergovaline, ppm & 0.95 & $<0.01$ & 1.36 & $<0.03$ & 1.00 & $<0.03$ \\
\hline
\end{tabular}

Table 2 Mean daily ambient temperatures during treatment.

\begin{tabular}{lllllll}
\hline & \multicolumn{2}{c}{----2004} & ---- & \multicolumn{2}{c}{---2005} & ---- 2006 ---- \\
& High & Low & High & Low & High & Low \\
\hline June, ${ }^{\circ} \mathrm{C}$ & 28.9 & 19.5 & 30.3 & 19.5 & 30.3 & 18.2 \\
July, ${ }^{\circ} \mathrm{C}$ & 30.5 & 20.2 & 32.3 & 22.2 & 32.7 & 21.3 \\
August, ${ }^{\circ} \mathrm{C}$ & 28.9 & 18.1 & 33.2 & 22.1 & 33.1 & 22.7 \\
\hline
\end{tabular}

Climatological data recorded by Nashville Office, National Weather Service, National Oceanic and Atmospheric Administration, U.S. Department of Commerce. 
effect of endophyte infection on goat growth and feed intake. From March to May in each year, does were fed orchardgrass hay ad libitum and a pelleted commercial concentrate $(454 \mathrm{~g} /$ head/day) for 2 months pretreatment. From June to August, the pelleted pretreatment feed was replaced with a textured feed to serve as the seed carrier. Endophyte-infected Kentucky-31 (EI) or endophyte-free Fawn (EF) tall fescue seed was added to the supplement $(227 \mathrm{~g} / \mathrm{head} /$ day $)$ for 10 weeks. Energy and protein levels were similar between the treatments (Table 1). In 2004, crossbred does were fed EI $(n=14 ; 31.6 \mathrm{~kg})$ or $\mathrm{EF}(\mathrm{n}=14 ; 31 \mathrm{~kg})$ seeds. The 2004 EI seed had 2.87 ppm of ergovaline; EF seed had less than $0.01 \mathrm{ppm}$. Diets were fed to three pens per treatment. Feed refusals were weighed daily. In 2005, straightbred Boer, Kiko, and Spanish does were fed EI $(n=18 ; 36.6 \mathrm{~kg})$ or $\mathrm{EF}(\mathrm{n}=18$; $36.4 \mathrm{~kg}$ ) for 10 weeks. The 2005 EI seed contained $4.13 \mathrm{ppm}$ of ergovaline; EF seed had less than $0.1 \mathrm{ppm}$. Diets were fed to three pens per treatment. Feed refusals were weighed daily. In 2006 , straightbred does were fed EI $(n=24 ; 39.1 \mathrm{~kg})$ or $\mathrm{EF}(n=24$; $37.9 \mathrm{~kg}$ ) tall fescue seed for 10 weeks. Data for two EF does were excluded because of internal parasitism requiring treatment. The 2006 EI seed contained 3.03 ppm of ergovaline; EF seed had less than $0.1 \mathrm{ppm}$. Diets were fed to four pens per treatment. Feed refusal values of EI pens were weighed daily and used to adjust feed offering to EF pens so intake was equalised during treatment. General goat management across treatments included providing water, orchardgrass hay and minerals for ad libitum consumption. Each year, doe genotypes were balanced across treatments and pen replicates. Ambient temperatures during the dietary treatments are presented in Table 2.

Weight gain and daily feed refusals were analysed by ANOVA using the GLM procedure of SAS (SAS Inst. Inc., Cary, NC) in a completely randomised design. Effects in the models included diet, doe genotype, and pen replicate within diet. Diet was tested using pen (diet) as the error term. Data for each year were evaluated separately. The protected LSD procedure was used to compare least squares means.

\section{Results and Discussion}

There were no genotype $\times$ diet interactions detected for weight gain. In 2005 and 2006, genotype influenced weight gain across diets $(\mathrm{P}<0.05)$ with Kiko gaining more than Boer does. Dietary groups had similar ADG during the pretreatment period, but does on EI diet had significantly reduced weight gain compared with those on EF during the treatment period of each year (Fig. 1). Lower growth rate is a commonly recorded response to EI tall fescue consumption in livestock (Stuedemann \& Hoveland 1988; Paterson et al. 1995). Growth responses to the EI diet in the goats of the current study were similar to growth responses in cattle observed at this location (Browning 2004). The reduced growth rate of goats as expressed here suggest negative consequences for the management of market kids and development of replacement breeding stock on EI tall fescue forage.

A reduction of feed intake is one of many behavioural and physiological changes that occur in animals exposed to the ergot alkaloids of EI tall fescue (Osborn et al. 1992; Aldrich et al. 1993; Paterson et al. 1995). Reduced feed intake may help to explain lower growth rates. In 2004 and 2005, feed refusals were higher in pens fed the EI diet (Fig. 2). Daily refusals were virtually all EI seed and represented 55\% and 34\% of seed offered in 2004 and 2005, respectively. Burns \& Fisher (2006) indicated that feed intake of goats tended to be reduced by wild-type endophyte infection of tall fescue hay when compared with non-infection or novel endophyte infection. The offering of seed in the current
Figure 1 Average daily weight gain (least squares mean \pm se) for meat goat does in (a) 2004, (b) 2005, and (c) 2006 during the pretreatment (Pre-) and treatment (TRT) periods. Tall fescue type (EI = endophyte-infected; $E F$ = endophytefree) affected $(\mathrm{P}<0.05)$ weight gain during the treatment period in each year.

a.

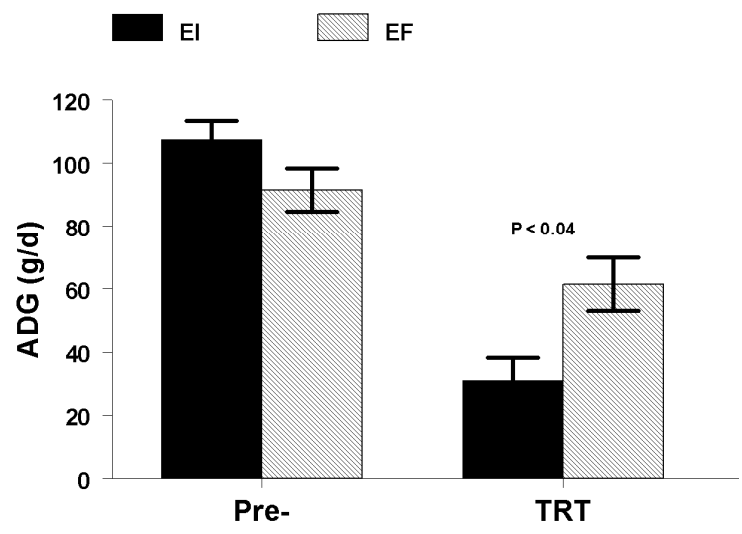

b.

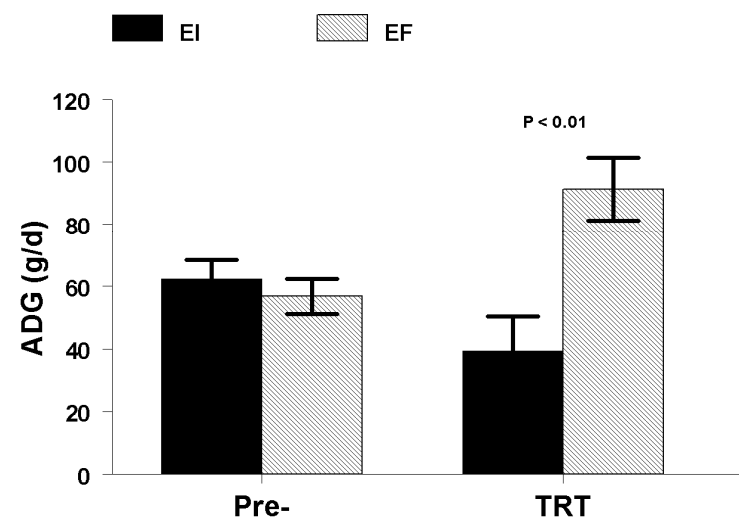

c.

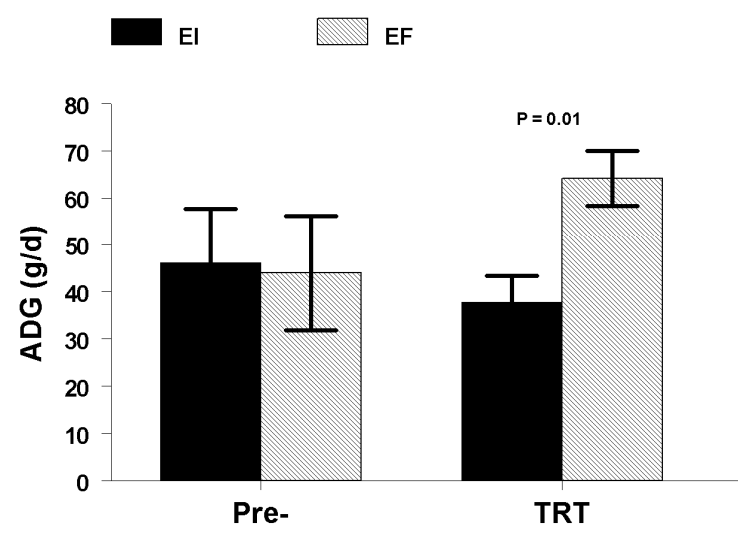


Figure 2 Average daily seed refusals (orts; Is mean \pm se) for meat goat does in 2004 and 2005 during the tall fescue treatment period. Tall fescue type (EI = endophyteinfected; $E F=$ endophyte-free) affected $(\mathrm{P}<0.05)$ seed refusals during the treatment period in each year.

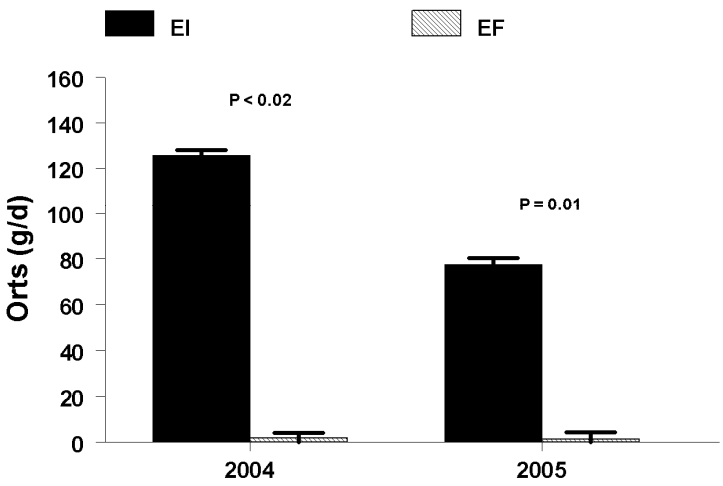

study was patterned after past work at this location on steers (Browning 2004). In the cattle work, there were no seed refusals and the steers exhibited various signs of hyperthermia. Goats in the current study did not show clinical signs of thermal distress. Goats are noted to be more selective feeders than cattle as evident by the ability of does to sort out EI seed when consuming the concentrate carrier.

When the daily offering to the EF pens in 2006 was adjusted each day based on the EI refusals, average orts were only $8 \mathrm{~g}$ / head/day ( $3.5 \%$ of offering), thus daily adjustments were minor. Nevertheless, the equalisation of feed intake in 2006 did not eliminate the difference in growth rate between EI and EF groups (Fig. 1c). As suggested in previous work on lambs (Fiorito et al. 1991), reduced growth rate of does on the EI diet seems to involve more than simply a reduction in feed intake. While not causing visible signs of animal discomfort, EI tall fescue lowered meat goat performance and altered feeding behavior. Further work into the impact of EI tall fescue on meat goat growth and reproductive rates may benefit this growing livestock industry.

\section{REFERENCES}

Aldrich, C.G.; Rhodes, M.T.; Miner, J.L.; Kerley, M.S.; Paterson, J.A. 1993. The effects of endophyte-infected tall fescue consumption and use of a dopamine antagonist on intake, digestibility, body temperature, and blood constituents in sheep. Journal of Animal Science 71: 158-163.

Bacon, C.W.; Siegel, M.R. 1988. Endophyte parasitism of tall fescue. Journal of Production Agriculture 1: 45-55.

Ball, D.M. 1997. Significance of endophyte toxicosis and current practices in dealing with the problem in the United States. pp. 395-410. In: Neotyphodium/Grass Interactions. Eds. Bacon, C.W.; Hill, N.S. Plenum Press, New York.

Browning, R. Jr. 2004. Effects of endophyte-infected tall fescue on indicators of thermal status and growth in Hereford and Senepol steers. Journal of Animal Science 82: 634-643.

Burns, J.C.; Fisher, D.S. 2006. Intake and digestion of 'Jesup' tall fescue hays with a novel fungal endophyte, without an endophyte, or with a wild-type endophyte. Crop Science 46: 216-223.

Fiorito, I.M.; Bunting, L.D.; Davenport, G.M.; Boling, J.A. 1991. Metabolic and endocrine responses of lambs fed Acremonium coenophialum-infected or non-infected tall fescue hay at equivalent nutrient intake. Journal of Animal Science 69: 2108-2114.

Foot, J.Z. 1997. Significance of endophyte toxicosis and current practices in dealing with the problem in Australia and New Zealand. pp. 389-393 In: Neotyphodium/Grass Interactions. Eds. Bacon, C.W.; Hill, N.S. Plenum Press, New York.

Glenn, A.E.; Bacon, C.W.; Price, R.; Hanlin, R.T. 1996. Molecular phylogeny of Acremonium and its taxonomic implications. Mycologia 88: 369-383.

Hibbs, C.M.; Wolf, N. 1982. Ergot toxicosis in young goats. Modern Veterinary Practice 63: 126-128.

Joost, R.E. 1995. Acremonium in fescue and ryegrass: boon or bane? A review. Journal of Animal Science 73: 881-888.

Kramer, R.; Keogh, R.G.; McDonald, M.F. 1999. Effects of ergovaline in endophyte- infected tall fescue on ewe fertility. Proceedings of the New Zealand Society Animal Production 59: 263-265.

Leite-Browning, M.L.; Muhammad, S.; Browning, R. Jr. 2002. A state-wide survey of goat producers in Tennessee. Journal of Animal Science 80 (Suppl. 2): 27 (abstr.).

Osborn, T.G.; Schmidt, S.P.; Marple, D.N.; Rahe, C.H.; Steenstra, J.R. 1992. Effect of consuming fungus-infected and fungus-free tall fescue and ergotamine tartrate on selected physiological variables of cattle in environmentally controlled conditions. Journal of Animal Science 70: 2501-2509.

Paterson, J.; Forcherio, C.; Larson, B.; Samford, M.; Kerley, M. 1995. The effects of fescue toxicosis on beef cattle productivity. Journal of Animal Science 73: 889-898.

Porter, J.K.; Thompson, F.N. Jr. 1992. Effects of fescue toxicosis on reproduction in livestock. Journal of Animal Science 70: 1594-1603.

Stuedemann, J.A.; Hoveland, C.S. 1988. Fescue endophyte: History and impact on animal agriculture. Journal of Production Agriculture 1: 39-44.

Wolfe, B.A.; Bush, M.; Monfort, S.L.; Mumford, S.L.; Pessier, A.; Montali, R.J. 1998. Abdominal lipomatosis attributed to tall fescue toxicosis in deer. Journal of the American Veterinary Medical Association 213: 1783-1786. 